\title{
FURNACES OF SALAMANCA: VERNACULAR BUILDING TECHNIQUES APPLIED TO SEMI-INDUSTRIAL TOBACCO PRODUCTION IN CHILE BETWEEN 1960 AND 1990
}

\author{
C. Gómez Maestro ${ }^{1}, *$ A. Rivera ${ }^{2}$, I. Olivares Miranda ${ }^{3}$ \\ ${ }^{1}$ Pontificia Universidad Católica de Chile, El Comendador 1916, Santiago, Chile - carmen.gomezmaestro@ gmail.com \\ ${ }^{2}$ School of Architecture, Universidad de Talca, Talca, Chile - amandariverav@ gmail.com \\ ${ }^{3}$ Ilustre Municipalidad de Salamanca, Salamanca, Chile - iva.olivares1@ gmail.com
}

\section{Commission II - WG II/8}

KEY WORDS: Vernacular building techniques, Industrialization, Earthquake-resistant devices, Adobe, Wood-earth techniques, Tobacco production

\begin{abstract}
:
The furnaces of Salamanca were built during the period in which the British Tobacco Company operated in this area of the Region of Coquimbo in Chile (1960's to 1990's). A semi-industrial model of tobacco production was inserted, in which local farmers received technical training and materials to grow tobacco plants. During a first period the company bought green tobacco leaves, while later encouraging the sale of dried tobacco. This meant that local producers had to build their own furnaces, under the company's technical instructions. These instructions were delivered through architectural plans produced by the company, which were interpreted by local farmers according to their own vernacular construction knowledge. This combination resulted in a huge variety of constructive techniques - primarily based on earth - represented in one only architectural form. A cadastre accomplished by the authors in 2019 registered examples of furnaces built with adobe, quincha, tabique and a combination of several of these building systems. Similar systems also present variations - expressed especially in the use of different earthquake-resistant devices. These attend to variable economic conditions and constructive cultures of the local farmers. This article presents the register of 24 furnace ensambles located in 7 areas of Salamanca, characterized according to their construction type and state of conservation. These entries provide information on the richness of vernacular construction of the area and the efficiency of case-specific building solutions.
\end{abstract}

\section{CONTEXTUALIZATION}

\subsection{The commune of Salamanca}

The commune of Salamanca is located in the Choapa Valley, within the Chilean Norte Chico. It is a semi-rural commune, set $510 \mathrm{~m}$ above sea level and distributed in three natural valleys. As the rest of Chile, it is emplaced in a highly seismic area and has withstood at least the major earthquakes of Vallenar in 1922, Ovalle in 1943, Punitaqui in 1997 and Canela in 2015 (Marchante, Rivera, 2020).

Before colonial times, the area was inhabited by the 'diaguitas', who were well known for their pottery and clay work (Cabello Baettig, 2016). These ancestors might as well have set the first trace of a long tradition in earth-construction, which is still visible nowadays throughout the territory. The commune's main town, also named Salamanca, was established in 1840 , thirty years after the country's independence. Since its foundation on grounds belonging to a spanish landowner, its largest development was associated to the arrival of modern technologies, particularly a railway line built in 1911 which connected the region with the country's main cities and harbours.

\subsection{Tobacco production in Chile and it's arrival to Salamanca}

The first registers of tobacco commercialization in Chile go back to colonial times, during which tobacco could be consumed, but not produced freely by local population. This prohibition was lifted briefly between 1811 and 1828 , a period in which tobacco production was controlled by the state and its benefits destined to cover military expenses associated to independence campaigns of neighbouring American countries. After some decades, in 1880, the government finally approved an act that liberated tobacco growth and cigarette sales, leading to a first industrial development based on artisanal production (Biblioteca Nacional, 2018a).

During almost two decades, small scale production of tobacco was combined with the growth of a few factories, which sustained most of the national tobacco production. The fusion of eight of these larger factories resulted in the foundation in 1909 of the Compañía Chilena de Tabacos (Biblioteca Nacional, 2018b). This company competed with the multinational British American Tobacco (BAT) until 1936, when both companies were fused into one single operator. This fusion initiated a modernization plan, which included new technologies and the rationalization of operation processes. Workshops were equipped with modern machines to elaborate and pack cigarettes, levelling Chilean production with the most advanced tobacco industries in the American continent. This development plan included the company's expansion and the establishment of new production sites throughout the country. In this context, a new production center was established in Salamanca in 1965.

The political setting which allowed for the creation of this new unit included the first agrarian reform introduced by president Jorge Alessandri Rodríguez in 1962 (Maturana, 2016).

\footnotetext{
* Corresponding author
} 
This reform transitioned from a feudal landowner system inherited from Spanish colonisation to a democratic system in which farmers could possess their own land. Salamanca was the first commune in the country to start this process, with the Corporación de Reforma Agraria (Corporation for Agrarian Reform) delivering agricultural plots previously belonging to the Choapas State in 1964

When the Compañía Chilena de Tabacos arrived to the area, many families who had recently received ownership of their land started growing tobacco under the supervision of the company. These same families would later build furnaces to deliver dried product.

Another determining factor for the development of tobacco production in the area was the existence of a railway which by 1958 already connected Salamanca with the country's main train axis. This line covered most of the Chilean geography, connecting producing areas with other cities and main ports along the coast, including Chagres, a town located in the Region of Valparaíso where dry tobacco bales where packed, tagged and distributed to their final destinations.

This railway line remained active until 1975 (CMN, 2004) and it's disappearance was associated to the end of the Compañia Chilena de Tabacos' activities in Salamanca in the 1980's. After this point, some farmers continued with small-scale tobacco production, which became increasingly difficult, not only due to the need to find direct purchasers, but also to a rise of fuel expenses. Tobacco production was fully discontinued in the area by the 1990's (Escudero, p.c., 2019).

\subsection{Tobacco production system in Salamanca}

One of the key steps for tobacco production is the drying of tobacco leaves. These must be harvested at an adequate time and dried in order to reduce their amount of chlorophyll and to allow for them to be lit. It is in this stage of production that relevant aspects such as taste, colour and aroma are fixed (Rolón et al., 2018). Tobacco drying systems vary around the world, mainly according to local climate conditions and to the availability of industrial technologies. In Salamanca, tobacco was dried in closed furnaces, in which warm air coming from combustion circulated through closed pipes, while temperature and humidity were controlled by simple mechanical means. This system had already been used in other parts of LatinAmerica (Rolón et al., 2018).

According to the testimony of local producers, the control of the drying process was the key to the production of high quality tobacco. During the first period of BAT's operation in Salamanca, this was difficult to accomplish. While the company had built 32 furnaces - originally with burnt bricks (Ventura, p.c., 2019) - around it's local headquarters, each batch needed between eight and ten days to dry and many farmers lost their production while waiting for their turn to dry their leaves. In this context, it seemed easier for each farmer to dry their own tobacco and deliver it directly to the Compañía Chilena de Tabacos.

In order to ensure that quality standards remained sufficient, the company technically assessed producers who wished to build their own furnaces, financing materials and teaching local building masters how they should be built.

\section{SCOPE OF THE INVESTIGATION}

\subsection{Aims}

The present article has the following aims:

- Cadaster examples of tobacco furnaces in the commune of Salamanca.

- Characterize building particularities of different furnaces, which were the result of vernacular interpretation of an architectural prototype imported by the Compañía Chilena de Tabacos.

- Assess the current state of conservation of these furnaces.

- Cross the previous information in order to assess factors concerning future conservation of the furnaces of Salamanca.

\subsection{Methodology}

The present article compiles information referred to 24 furnace ensambles, located in seven different sectors of Salamanca. This information is gathered during fieldwork developed in April of 2019 , through photographical surveys and in-situ assessment of their state of conservation. This is complemented with other information previously produced by the local government of Salamanca, which included basic architectural drawings of some furnaces and interviews with different owners (Olivares, 2018). Other complementary sources of information are the detailed drawings and group interviews to local historians, politicians and other members of the community, carried out by teachers and students of the post-graduate Diploma on Earth Building of the Pontificia Universidad Católica de Chile in August of 2019.

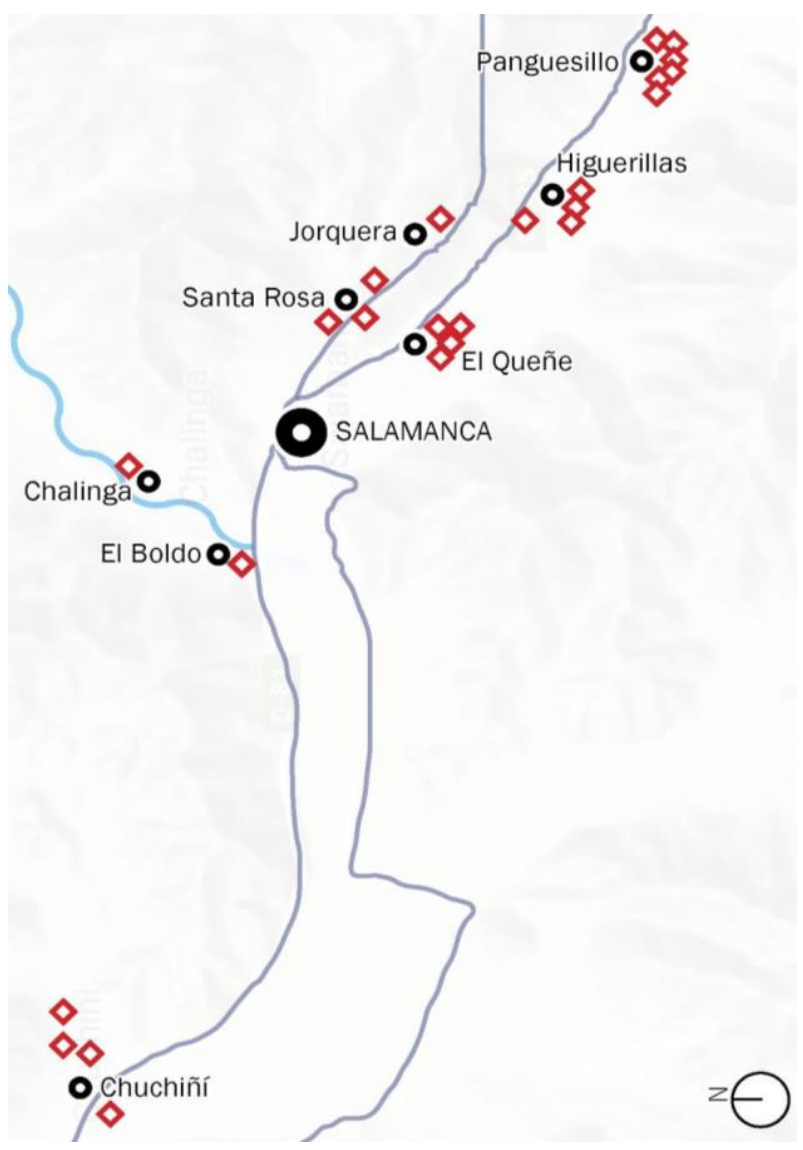

Figure 1. Location of the 24 studied ensembles (in red) within settlements of the commune of Salamanca (in black). 
Gathered information is systematized according to the aims of the investigation, considering criteria provided by the national norm on earthen heritage (NCh 3332).

\section{THE FURNACES OF SALAMANCA}

\subsection{Architecture}

Tobacco drying was a critical process to reach quality standards desired by the Compañia Chilena de Tabaco. This is why the company detailed both the architectural form and mechanical features of furnaces to all farmers producing on its behalf, searching to optimize production time and costs.

Architectural plans were rectangular, measuring approximately 6 by 7 meters. The walls were about 6 meters high, while the ridge could rise up to 8 meters above the ground. Furnaces would usually have one or two doors to introduce and extract tobacco plants and a single window located on the upper part of the enclosing walls. This window, along with other mechanisms, such as mobile ridges and wooden portholes on the lower area of the furnace, allowed for ventilation and a better control of humidity and heat conditions.
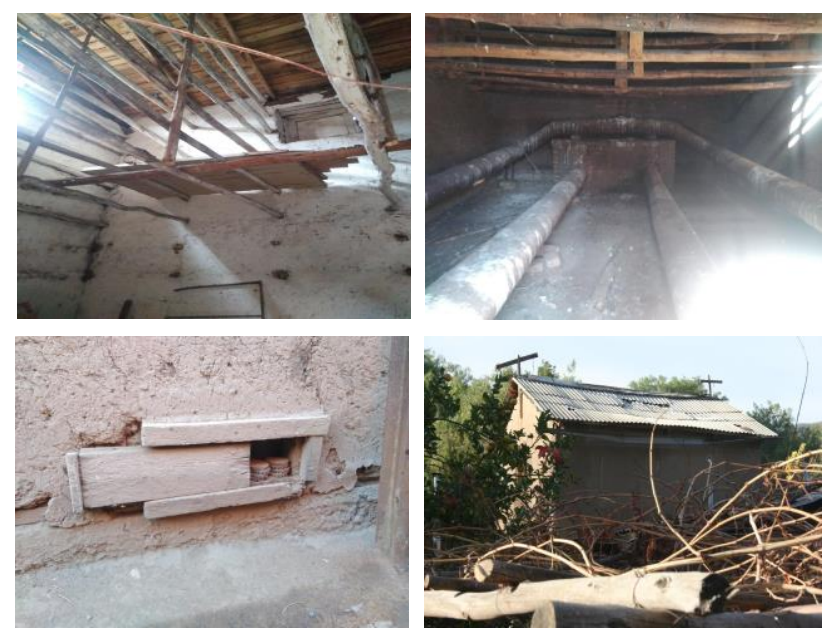

Figure 2. Mechanical features designed to enhance tobacco drying. a. Poplar logs were used to hang tobacco leaves b. Iron tubes conducted hot air through the furnace $\mathrm{c}$. Wooden portholes controlled air intake in the furnaces d. Ridges could be lifted mechanically to allow for better ventilation.

Green tobacco leaves were threaded and hung on canes, which were laid between poplar logs which covered the inner width of the furnaces. Once the tobacco plants were hung, furnaces were heated with ovens, which were always located outside them. Hot air was conducted from these ovens through iron pipes, which toured inside the furnaces and finally ventilated through a chimney on the outside. Both ovens and the wall segment through which these pipes entered and exited the furnace were built with burnt bricks. During the years in which tobacco furnaces operated, different fuels - gas, paraffin or firewood were used to heat them up. Fuel choice influenced on production times, costs and processes, but not on the architectural or building distribution of furnaces.

\subsection{Furnace ensambles}

As a consequence both of land distribution and externalization of drying processes, tobacco furnaces in Salamanca are grouped in different ways. Each producer built a different number of furnaces according to the number of hectares they destined to tobacco plants, which was also linked to their previous economical power. These were usually built along several years.

While many furnaces appear isolated in small plots of land and belonged to almost artisanal-scale producers; others are arranged in groups that range from two up to eight furnaces. Larger complexes were linked to each other through precarious corridors, which protected both workers and production from the sun or, most rarely, from the rain. The lesser amount had complementary infrastructure to support production. This is the case of a complex in Santa Rosa, in which four ovens were connected by a concrete platform with differentiated heights to ease the manipulation of tobacco during its manufacturing stages. In this same unique example, other complementary adobe constructions were built to be used as storage space and to host the person in charge of supervising fuel combustion.

\begin{tabular}{|c|c|c|c|c|}
\hline Location & $\begin{array}{c}\quad \mathbf{N}^{\circ} \text { of } \\
\text { registered } \\
\text { ensembles }\end{array}$ & $\begin{array}{c}\mathbf{N}^{\circ} \text { of } \\
\text { registered } \\
\text { furnaces }\end{array}$ & $\begin{array}{c}\text { Meann } \\
\text { furnaces } \\
\text { per } \\
\text { ensemble }\end{array}$ & $\begin{array}{c}\text { Main } \\
\text { building } \\
\text { system }\end{array}$ \\
\hline Panguesillo & 6 & 8 & 1,3 & Adobe \\
\hline Chuchiñi & 4 & 14 & 3,5 & Adobe \\
\hline Higuerillas & 4 & 10 & 2,5 & Adobe \\
\hline El Queñe & 4 & 4 & 1 & Tabique \\
\hline Santa Rosa & 3 & 10 & 3,3 & Adobe \\
\hline Chalinga & 1 & 4 & 4 & Mixed \\
\hline Jorquera & 1 & 4 & 4 & $\begin{array}{c}\text { Brick or } \\
\text { adobe }\end{array}$ \\
\hline El Boldo & 1 & 2 & 2 & Tabique \\
\hline
\end{tabular}

Table 1. Main building systems and ratio of furnaces per ensemble in each studied location.

\subsection{Building systems and techniques}

One of the main results of the encounter between vernacular building knowledge and the replication of a single architectural design was the use of different building techniques to reach a same objective. These techniques can also be found in other constructions throughout the Chilean Norte Chico.

Most of these techniques are based on adobes - raw earth bricks which are used to build bearing masonry walls or set edgewise within wooden structures as an infill. This second system is known as 'tabique de adobe en pandereta' (Rivera, 2017) or 'tabique'. 
The predominance of each technique was different in each of the studied locations, in which not only a preference for a certain system was identified, but also certain variations to each technique, suggesting a diverse previous local knowledge (Table 1).

3.2.1 Adobe: This bearing wall system was made of large earthen bricks and was the most commonly found among the furnaces of Salamanca. This is also one of the most frequently found techniques across the country, in which the most common block size is $60 \times 30 \times 10 \mathrm{~cm}$. Furnaces combine this block size in their upper part with a slightly larger $(60 \mathrm{x} 40 \mathrm{x} 10 \mathrm{~cm})$ block on their lower area. Both blocks are disposed in stretcher bonds, resulting in half-brick thick walls in all of the furnaces' height (Figure 3). This manner of construction is an early example of what Jorquera and Rivera (2017) call 'new adobe', which widespread in the Norte Chico area from the second half of the 1990's onwards.

The difference with older adobe constructions - normally built with header bonds that result in $60 \mathrm{~cm}$ wide walls - lies on the slenderness of these bearing elements. While small slenderness is widely identified as one of the keys for appropriate structural performance of adobe bearing systems, particularly under seismic conditions; studied furnaces have slenderness ratios above 15 , which are far larger than the maximum of 8 set by the national norm.

Nevertheless, these cases recurrently incorporated horizontal wooden elements. These elements are set between adobe layers at different heights, either wrapping the whole perimeter of the construction, or just reinforcing corners. They are materialised differently in each of the studied locations - mostly through a different amount of reinforcements per furnace and different wood sizes and joints in each element - and would help to counteract large slenderness ratios, therefore contributing to the better seismic performance of these buildings. Damage due to biotic or anthropic factors in these wooden reinforcements is found to be related to the general conservation of furnaces and to severe damage in adobe walls (Figure 8). In parallel, poplar logs used to hang tobacco leaves were frequently anchored directly into adobe walls (Figure 2a). This thick concentration of horizontal links between parallel planes of furnaces would have also mitigated the effect of high slenderness ratios.

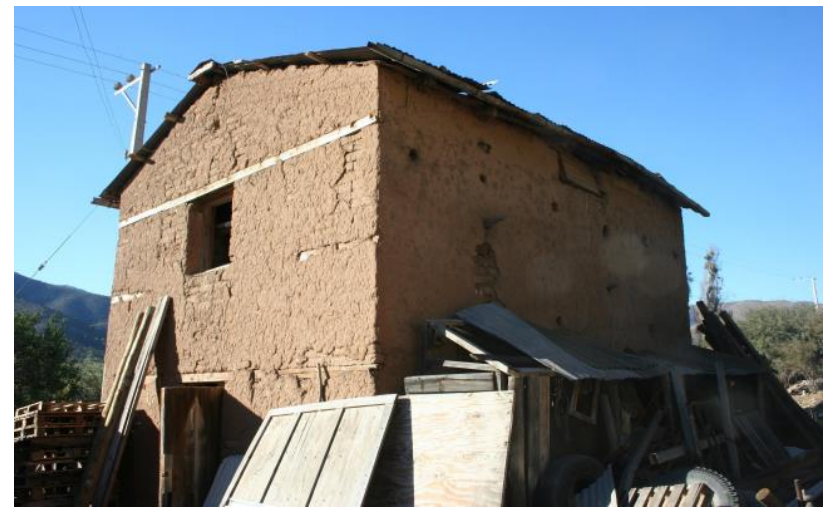

Figure 3. Adobe furnace in Chuchiñí, in which both continuous and corner horizontal wooden reinforcements can be identified.

3.2.2 'Tabique': The second most common building system among the cadastered furnaces is 'tabique de adobe en pandereta'; a hybrid wood-earth technique in which the bearing structure is made of wood, while adobe blocks are used only as an infill. In this system, adobes are set on their thinner edge and confined with metal wires. These are nailed to the main wooden structure on their outside and inside to keep adobes from falling from the wall's axis. Wooden structures present variations within the studied cases, both in the geometry of the wood and in its section and structural logic. In the particular case of El Boldo, for example, two furnaces belonging to a same ensemble are built using different techniques. The first of them was built with unsawn wood, which shows natural irregularities in a pile and beam system and in which acacia pillars were directly buried into the ground. The second example is erected with sawn upper, lower and diagonal hearths of poplar (Ventura, p.c., 2019)following an adapted balloon frame system with concrete foundations. This system is found more commonly than the first throughout the studied areas (Figure 4).

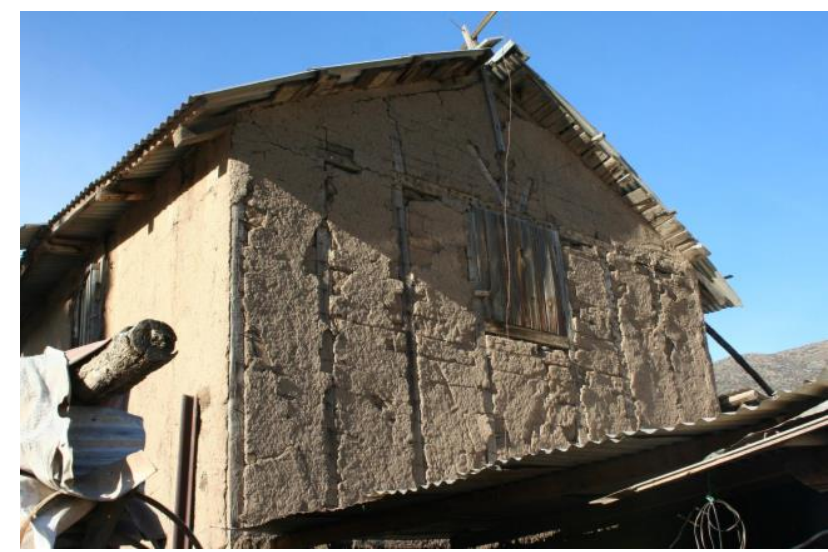

Figure 4. 'Tabique' furnace in El Queñe with one horizontal block between the sawn wooden elements and horizontal wires.

On the other hand, differences were also observed in the way of arranging adobe blocks which infill wooden structures. Spaces between wooden pillars can be filled either with one single horizontal block or with several of them, set vertically. A last difference lays in the distribution of metal wires confining the adobes, which were found to be arranged horizontally or diagonally in different cases. Vertical adobe arrangements and horizontal wiring distribution were shown to be more vulnerable to emptying due to dynamic forces of earthquakes (Figures 5a, $5 \mathrm{~b}$ and $5 \mathrm{c}$ ).
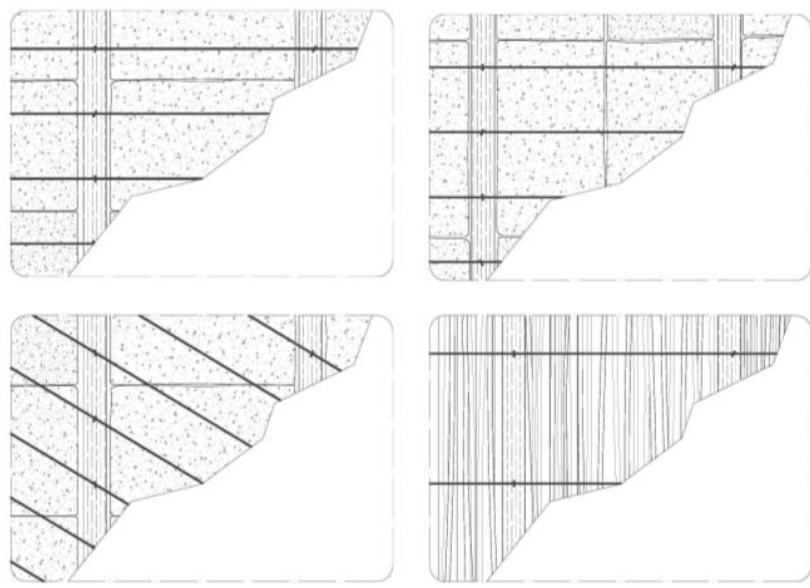

Figure 5. Squemes showing variations in tabique and quincha infills. a. 'Tabique' with single horizontal adobe and horizontal wiring b. 'Tabique' with double vertical adobes and horizontal wiring c. 'Tabique' with single horizontal adobe and diagonal wiring d. 'Quincha' with vertical tobacco branches confined with horizontal wiring. 
3.2.3 'Quincha': A third technique found in the area is the branch-filled 'quincha'. This is another hybrid wood-earth technique, in which the bearing structure is made of wood. Variations within these structures are similar to those found in furnaces built with 'tabique de adobe en pandereta'; with the difference that 'quincha' walls are not filled with adobes but with a combination of medium-sized vegetable fibers and earthen plasters. This technique was only observed in the upper level of one of the studied furnaces (Figure 8) and in minor elements such as gables in other studied cases. In the first, fibers correspond to tobacco branches, which are confined externally with horizontal metal wires and then covered with earthen and wheat straw plasters (Figure 5d).

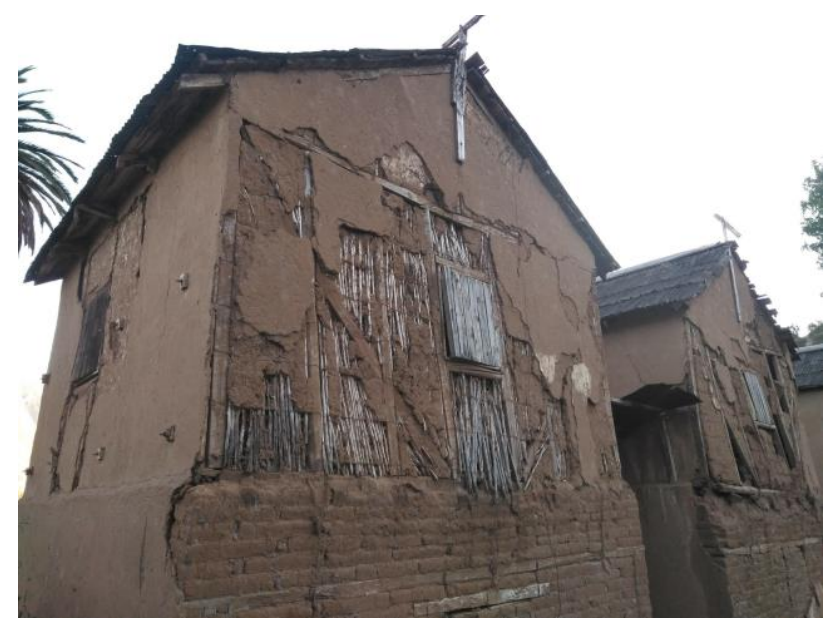

Figure 6. A singular case of 'quincha' in Chalinga. The lower area is built with adobe.

\section{CURRENT STATE OF CONSERVATION}

\subsection{Contemporary use of the Salamanca furnaces}

After the disapparition of the Compañía Chilena de Tabacos in the 1980's, the productive use of furnaces declined and was finally abandoned in the 1990's (Escudero, p.c., 2018). The specificity of the architectural design of these buildings does not indicate an obvious transformation in their use and while they are recognised by the community of Salamanca as 'extremely valuable' due to their link to a relevant period of the commune's history (Group interview, p.c., 2019), most furnaces in Salamanca are nowadays used as storage spaces for other agricultural labour or have been abandoned.

In the first case, this change in use has implied the extraction of the antique heating system, which was placed in the lower area of the furnaces, making storage difficult. Some furnaces which are now used as storage have been lowered, in order to ease cleaning tasks and to reduce their slenderness; thus supposedly increasing their structural capacity. This transformation has nevertheless not always been successful, since the extraction of continuous wooden reinforcement on the upper area of walls is associated to the appearance of new, deep cracks in these constructions (Figure 7).

Only one of the studied ensembles is currently incorporated as a cultural and touristic asset. In spite of their poor state of conservation, the furnaces of Chalinga (Figure 6) stand near a neo-colonial house which is currently used as a modest museum and community meeting centre. This ensemble is managed by the owner's family and relies only on payment coming from visitors for its maintenance.
Many furnaces were disassembled by their owners in order to make more space within their plots, reuse materials or prevent them from naturally falling down due to lack of maintenance.
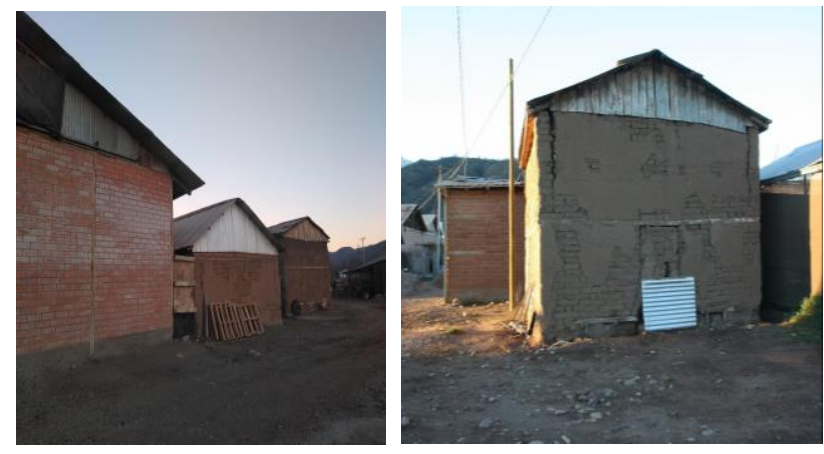

Figure 7. Lowered furnaces in Chuchiñi.

\subsection{Damage}

The preliminary assessment of the 24 registered ensembles shows a range of states of conservation. While many of them have withstood time and lack of use and maintenance for the last decades without major damage; others present severe structural problems which endanger their conservation.

Considerations to classify damage as major, medium or minor include the existence of isolated or combined structural damage, damage severity and the combination of one or more wearing effects when inspection was undertaken. While roofing systems are essential for long-term conservation and their deterioration should be considered in further studies, this preliminary damage assessment is centered exclusively on earthen walls.

\section{Preliminary \\ Used building system \\ damage \\ assessment}

\section{Adobe Tabique Mixed TOTAL}

Ruin

1

0

0

Major

3

1

1

Medium

3

0

0

Minor

9

2

0

Unregistered

2

2

0

TOTAL 18 5

1

Table 2. Summary of preliminary damage assessment in cadastered furnace ensembles. 
This assessment showed that most wearing effects are recurrent in different case studies and can be classified into three different groups. While some of them - particularly those involving wooden elements - affect all furnaces equally, others can be associated to particular building systems.

4.2.1 Cracks: Those which compromise the structural capacity of furnaces appear mostly on adobe walls. Severe inplane cracking of the walls was observed in some cases, particularly in those where horizontal wooden reinforcements were not present or deficiently designed - with poor link between the wood elements and insufficiently distributed in their total height (Figure 8). Cracks appear most commonly in corners and in higher parts of furnaces, particularly in adobe gables.
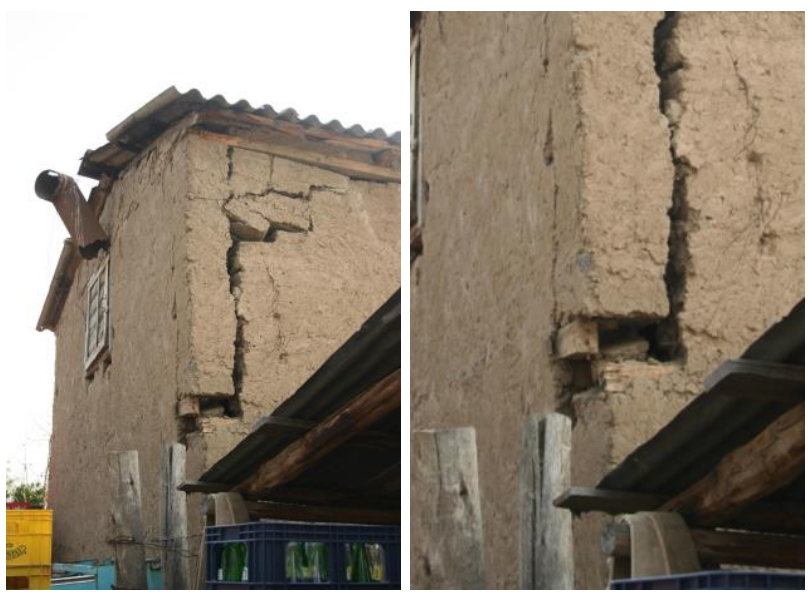

Figure 8. Crack in a furnace in Panguesillo, associated to poor links within its horizontal wooden reinforcement.

4.2.2 Material loss: Material loss is a general classification of three particular damages: plaster loss, erosion and voids. While the first is common to all studied furnaces -triggered either by environmental or mechanical factors affecting adherence to different surfaces such as adobe blocks or wooden structural elements - erosion affects mostly adobe structures in their lower or upper areas and it is due to water infiltration or splatter. This damage rarely compromises structural stability of studied cases.
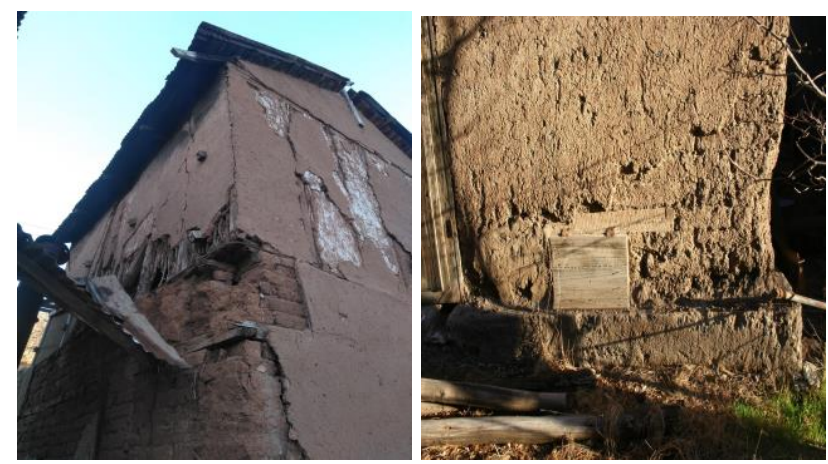

Figure 9a. Erosion in a. upper area of an adobe wall in Chalinga b. lower area of an adobe wall in Chuchiñi.

On the other hand, voids appear almost exclusively in tabique and quincha structures. Voids in hybrid wood-earth techniques occur mainly due to failure of secondary structure. This was associated either to deterioration of metal wires confining fallen blocks or most commonly - to the position of the filling it-self.
4.2.3 Wood damage: Wooden structures are a relevant part of furnaces in Salamanca. They constitute bearing structures in 'tabique' and 'quincha' constructions, while wooden reinforcements are a fundamental item of bearing adobe systems. Wooden beams covered by metal planks are also used to roof all studied furnaces.

On-site assessment detected major damage in wooden structures in the area, ranging from deformation of roofs, with the consequent risk of water infiltration - even if Salamanca is a mainly dry region - and deterioration of reinforcements within adobe walls. Much of this damage is associated to the large presence of xylophagous insects in the area and becomes especially severe in cases where wood is exposed to water (Figure 9a).

Another recurrent issue detected in the deterioration of wooden structures is the poor choice of wooden joints in some specific cases, which lead to major deformation of walls (Figures 8 and 10).
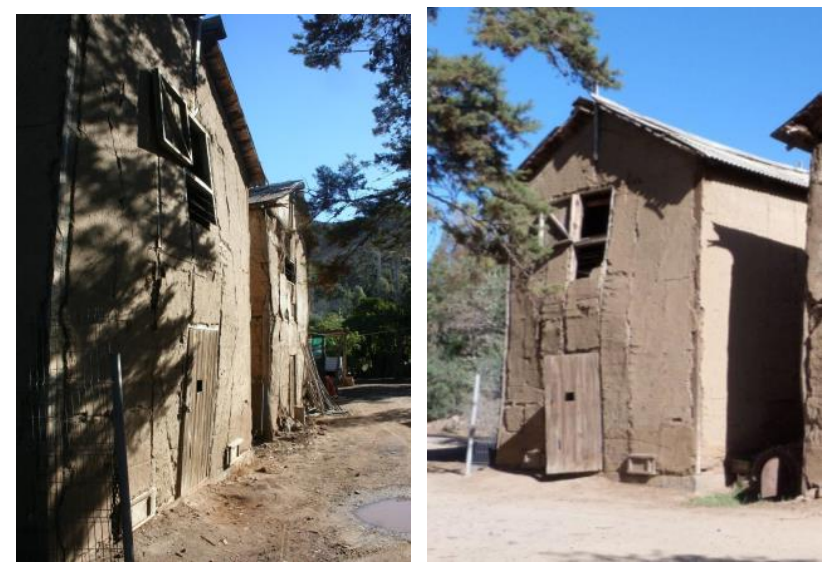

Figure 10. Severe deformation of a tabique wall associated with an inappropriate choice of wooden joints in pillars - Furnace in El Boldo.

\section{CONCLUSIONS}

The furnaces of Salamanca offer a rare opportunity to develop a comparative study of similar building types with subtle variations, applied to a single architectural form. This is considered a chance to study the effectiveness of particular building solutions through the comparison of a detailed analysis of their singularities and a full pathological diagnosis of their damages. This is deemed to be particularly useful in a country with high seismic risk and little regulation of earthen constructions.

A first approximation to these aspects already shows some preliminary results. In general, furnaces built completely with tabique are found to have more severe damage than others built completely with structural adobe masonry walls. Main damages are associated with voids in block infills, which are particularly frequent in cases where two or more blocks are arranged between consecutive vertical elements of the wooden structure. On the other hand, wire confinement is shown to be highly vulnerable due to oxidation and detachment from its holder. Still, infills confined diagonally seem less vulnerable than those materialized with horizontal wire confinements - even if both are realized with the same material. In this same sense, the important presence of xylophagous insects is a relevant cause of deterioration, both of wooden elements and their connection to confining elements. These, along with meteorological factors, are active agents of deterioration which will continue damaging furnaces in the middle and long term unless tackled. 
These biological agents equally affect adobe furnaces, since they deteriorate their wooden reinforcements. Structural adobe furnaces generally show better behaviour than those built with tabique - even if they do not comply with the slenderness ratios recommended for this type of constructions - particularly when they have continuous reinforcements. In these cases appropriate joints and assemblies of wooden elements inbuilt in walls or set on wall ridges, embedded poplar beams used to hang tobacco and roofs are considered determinant to collaborate in the stability of these buildings. In this sense, the fact that greater structural damage is associated with wooden elements than to the deterioration of earthen materials is considered a chance to promote preservation of vernacular earthen and mixed techniques in the area. These are widely present in local built heritage and have been largely discredited in the past by local and national authorities (Gómez, 2014).

Most standing cases are built with adobe, which suggests either a local preference for this system or the lesser efficiency of other systems in withstanding time. While the second theory appears to be sustained by larger damage in studied cases built with tabique or quincha; this should be contrasted with information regarding furnaces which have already disappeared in the past.

Contrasting information from these disappeared furnaces and those that are still standing is considered relevant to determine other factors of conservation. This will be the subject of future research. If this study is carried out, it is considered essential to record the conditions of the terrain on which the different furnaces stand, as well as the characteristics of the earthquakes that affected them since their construction and other particular environmental factors.

As for the preservation of heritage values embedded in the tobacco furnaces of Salamanca - both regarding vernacular building knowledge and the representation of a relevant period of Salamanca's history - future uses of this infrastructure should be assessed.

At present, even if most owners identify the lack of use of furnaces as one of the main threats to their conservation, there is no refunctionalization plan for these structures at a territorial level, which leaves any possible action to their owners. Considering their current functional obsolescence, the absence of official protection and formal valuation of this heritage is considered another vulnerability factor. These threats join previously identified vulnerabilities associated to physical deterioration.

As for the social assessment of these ensembles, the local community highlighted the relevance of tobacco production in the commune's history and its impact on its identity. While furnaces in their current form were scarcely appreciated, interviewees did recognize the value and relevance of earthen construction techniques. The desire for knowledge on these techniques and local history to be widespread was general, as well as the idea that this promotion should be lead by official institutions. In this sense, the local government was primarily identified by the community as the main actor for articulated conservation. Nevertheless, this preliminary assessment did not contemplate that even if local authorities are interested in preserving furnaces and their heritage, their management capacity is limited to a single permanent asset: a small team of three people with many other responsibilities linked to the cultural development of the commune. This force is deemed to be insufficient to promote effective protection and should be reinforced externally or internally if any action for the furnaces conservation is to be undertaken in the future.

\section{REFERENCES}

Biblioteca Nacional. 2018a. Memoria Chilena. Visited 20th of January of 2020, from Industria del tabaco en Chile: http://www.memoriachilena.gob.cl/602/w3-article-97859.html

Biblioteca Nacional. 2018b. Memoria Chilena. Visited 20th of January of 2020, from El tabaco y sus cajetillas: http://www.memoriachilena.gob.cl/602/w3-article-97859.html

Cabello Baettig, G., 2016. A brief history of the diaguita culture before the arrival of the spanish conquistadors. The Art of Being Diaguita. Santiago: Museo Chileno de Arte Precolombino. 1544.

Consejo de Monumentos Nacionales (CMN). 2004. Visited 15th of January of 2020, Estación de Ferrocarril de Salamanca: https://www.monumentos.gob.cl/monumentos/monumentoshistoricos/estacion-ferrocarril-salamanca

Gómez, C., 2014. Casona de Chanco: Estrategias de reconstrucción post-sismo en áreas patrimoniales del Valle Central Chileno. Valencia: Laboratorio Hilberseimer Universidad Politécnica de Valencia. 59-65.

Guzmán E., 1979. Curso elemental de edificación. Facultad de Arquitectura y Urbanismo de la Universidad de Chile. Santiago: Editorial Universitaria.

Jorquera, N., Rivera, A., 2017. Continuidad y discontinuidad de las técnicas de tierra en Canela, Chile, epicentro del sismo 8,4 mw de 2015. Seminario Iberoamericano de Arquitectura y Construcción con Tierra, 17 Memorias... La Paz, Bolivia: PROTERRA/FAADU-UMSA. 672-681.

Maturana, A. 2016. Apuntes sobre la Historia de Salamanca. Santiago: Ediciones on Demand.

Rivera, A., 2016. EL ADOBE Culture sismique chilienne, étude de cas : le "Norte Chico". Grenoble: CRAterre-ENSAG

Rivera, A., 2017. The Chilean adobe as a seismic vernacular technology, the study of the "Norte Chico" zone. Vernacular and Earthen Architecture: Conservation and Sustainability. London: CRC Press. 675-680.

Rolón, G., Herr C., Jerez Lazo, P., Fernández, A., Lamas, M., 2018: Las estufas de secado de tabaco en Salta. Problemáticas de un parque edilicio e refuncionalización. Seminario Iberoamericano de Arquitectura y Construcción con Tierra, 18 Memorias... La antigua Guatemala, Guatemala: USACCII/PROTERRA, 29-36.

Stovel, H., 2003. Preparación ante el riesgo: Un manual para el manejo del Patrimonio Cultural Mundial. Rome: ICCROM. 